\title{
Climbing through the Milwaukee County Civil Commitment Process
}

Jon A. Lehrmann, MD

Medical College of Wisconsin in Milwaukee

Follow this and additional works at: https://jdc.jefferson.edu/jeffjpsychiatry

Part of the Psychiatry Commons

Let us know how access to this document benefits you

\section{Recommended Citation}

Lehrmann, MD, Jon A. (1993) "Climbing through the Milwaukee County Civil Commitment Process," Jefferson Journal of Psychiatry. Vol. 11 : Iss. 2 , Article 10.

DOI: https://doi.org/10.29046/JJP.011.2.007

Available at: https://jdc.jefferson.edu/jeffjpsychiatry/vol11/iss2/10

This Article is brought to you for free and open access by the Jefferson Digital Commons. The Jefferson Digital Commons is a service of Thomas Jefferson University's Center for Teaching and Learning (CTL). The Commons is a showcase for Jefferson books and journals, peer-reviewed scholarly publications, unique historical collections from the University archives, and teaching tools. The Jefferson Digital Commons allows researchers and interested readers anywhere in the world to learn about and keep up to date with Jefferson scholarship. This article has been accepted for inclusion in Jefferson Journal of Psychiatry by an authorized administrator of the Jefferson Digital Commons. For more information, please contact: JeffersonDigitalCommons@jefferson.edu. 


\title{
Climbing Through the Milwaukee County Civil Commitment Process
}

\author{
Jon A. Lehrmann, M.D.
}

\begin{abstract}
Civil commitment has become a practically unavoidable process for today's practicing psychiatrist. It creates a complicated triangular relationship involving the legal system, the medical system, and the patient.

This article is a first person narrative of a case which helps describe the Wisconsin civil commitment process as it operates in Milwaukee County. It illustrates the frustrations that a psychiatrist (and in this case a first year psychiatry resident) can experience in such a system. Finally, it addresses these problems associated with civil commitment and discusses possible solutions.

I first became initiated into the Milwaukee County (Wisconsin) civil commitment process during my first year of psychiatry training. During my first testimony, I had been questioned satisfactorily by the patient's attorney, and then the County attorney asked me confidently, "Doctor, how long have you been a psychiatry resident?" I answered, "about two weeks." When the judge and everyone else in the courtroom finally stopped laughing and my embarrassment had faded, we were able to put the focus back on the issue at hand.

With that being my introduction to the frustration of the Milwaukee County civil commitment system, I now use it as a prologue for a case report which illustrates many of the shortcomings of that system, as well as the complexity of the Wisconsin laws of commitment, as they are practiced in Milwaukee County. Working with this patient showed me the importance of the interface between the legal system and psychiatry. This is the case of J.S. (certain identifying features have been changed for the sake of confidentiality).

J.S. is a 41 year old woman diagnosed with chronic schizophrenia. She had been hospitalized many times over the last 20 years secondary to psychotic states which usually occurred after Miss S. had stopped taking her prescribed neuroleptic medication. She became quite dangerous at these times developing delusions focused on a need for excessive weight loss. In May of 1990, Miss. S. was hospitalized under similar circumstances. Two months previous to this admission, because of a similar episode of dangerous weight loss, her father had been appointed her temporary guardian.
\end{abstract}

Jon A. Lehrmann, M.D. is a PGY-III resident in the Department of Psychiatry at the Medical College of Wisconsin in Milwaukee. 
In May, the temporary guardianship was still in effect, and this allowed the patient to get proper medical care even though she refused it. Miss S. had to be placed in an unlocked psychiatric unit. After a few days of intravenous hydration, receiving medication, and a limited amount of cooperation with feedings, she left the unit against medical advice (she simply ran away). Her parents finally caught up with her in Chicago, but the temporary guardianship had run out. They convinced her to come home. Because of concerns about her health, the family pursued a Three Party Petition (P.E.) for examination. [A P.E. is a method to pursue commitment, and it requires the signatures of three separate parties as well as written evidence that the individual in question is mentally ill and/or drug dependent or developmentally disabled and dangerous. The document must be filed at the courthouse and accepted by a judge before the individual will be picked up by the police. Within 48 hours from admission to the Milwaukee County Mental Health Complex (MCMHC), a Probable Cause Hearing (precommitment hearing) will be held.] J.S. was picked up by the police shortly thereafter. This time she was admitted to one of the locked psychiatric units at MCMHC, and that's when I first met her. It was July of 1990, and I was in the first month of my psychiatry training.

Miss. S. presented as an extremely thin, quiet woman. Her affect was flat, and she seemed to stare through me. She was isolative, but with encouragement she reluctantly participated in unit activities. Miss. S. ate limited portions of specific foods - cheese and fruits. She reluctantly cooperated with interviews. J.S. discussed a recurrent delusion that she was a "marathon runner" and that she was currently attempting to "get in shape for distance running" and that to do this she needed to decrease her intake of food and fluid. She reasoned that because she couldn't walk far, let alone run, at her present weight, if she weighed less she could run a marathon.

With counseling from her attorney, Miss. S. signed a Thirty Day Voluntary Case Suspension Agreement (V.C.S.A.) [A V.C.S.A. is an agreement which places the commitment procedure on hold for up to thirty days as long as the patient and psychiatrist are in agreement. If at any time during that period the psychiatrist feels that for lack of compliance or other reasons the commitment process needs to be pursued, the V.C.S.A. can be rejected and the commitment proceedings are resumed.] Miss S. reluctantly began to comply with diet and medications. Control issues were a point of contention. She continually refused the Prolixin decanoate (long-acting, depot form of neuroleptic medication) as a recommended form of medication. Miss S's delusions did seem to become less fixed. At the end of the V.C.S.A., the delusions persisted, although she had begun to question the reality of them. We didn't feel that she was ready for discharge yet, and recommended a thirty day extension onto the V.C.S.A. J.S. reluctantly agreed to the extension to avoid resumption of formal commitment proceedings.

Over the next three weeks Miss S's compliance and activities of daily living improved, and her delusions dissipated. Having done well with home passes, she was discharged with follow-up psychiatric care scheduled with me. By our second appointment, J.S. looked disheveled and demonstrated a disorganized thought process. She refused to let the home health-care nurse into her supervised apartment. She refused 
offered medications as well as laboratory work and weight measurement. Miss S. missed our next appointment, and I phoned her to discuss my concerns. She slurred her words, but reluctantly agreed to let the nurse in to see her. I arranged it immediately. The nurse phoned me from J.S.'s home. J.S. had lost forty-two pounds over the last seventeen days, twenty-six percent of her pre-discharge weight. Her medication bottles were full. She had an elevated pulse rate. Miss S. refused to come into the hospital. I notified my supervisor and called the police. The police officers who responded phoned me and stated that they did not feel Miss. S. looked sick enough to be placed on Emergency Detention (An E.D. is a police hold which allows the individual to be legally held against his/her will for up to twenty-four hours because of behavior which a police officer feels is dangerous to the individual or others. There must also be evidence that the individual's dangerousness is in some way related to mental illness and/or drug dependence or developmental disability.] I tried to discuss my concerns to no avail. They noted Miss S. had partially eaten cheese in the refrigerator and felt this to be adequate nutrition. Because of our deep concern, my supervisor called their precinct supervisor. To convince him, my supervisor had to tell him that he was responsible for our patient's welfare, and that she would die if they did not respond. Finally, Miss S. was taken to the medical emergency room on an E.D.

The emergency room physician found J.S. to have life-threatening dehydration. She had postural hypotension, tachycardia, and her serum sodium $=169 \mathrm{meq} / \mathrm{l}$ (normal values-135-145), serum blood urea nitrogen-196 mg/dl (normal values$7-20$ ), and serum creatinine $=4.2 \mathrm{mg} / \mathrm{dl}$ (normal values - $0.6-1.0$ ). (Her lab values had been within normal parameters three weeks previously). Miss S. received several liters of intravenous fluid and was sent to the MCMHC for admission. A Treatment Director's Supplement (a T.D.S. is a supplemental legal document filed by the physician which allows the legal hold to be extended for another forty-eight working hours beyond the E.D. at the end of which a Probable Cause Hearing is held) was filed the next morning prior to transfer back for further stabilization. This time, J.S. was admitted to the medical hospital for further hydration. After stabilization of her electrolytes, she was transferred back to the MCMHC inpatient psychiatric unit. This time the legal hold was erroneously lost when Miss S. was admitted as a voluntary patient. The next day the patient filed a Request for Discharge (R.F.D.) form. From the time an R.F.D. is file, the treating physician has twenty-four hours to either release the voluntary patient or file a Treatment Director's Affidavit (T.D.A.) to detain the patient. The T.D.A. is a legal document the physician must file which asserts that the patient is mentally ill and/or drug dependent or developmentally disabled and a danger to himself/herself or others. I filed the T.D.A. A Probable Cause Hearing was arranged within forty-eight hours. The patient was provided an attorney, and a V.C.S.A. was filed in order to avoid commitment. My supervisor and I rejected the V.C.S.A. in order to pursue commitment (commitment is a six month legal hold on an individual which obligates him/her to be in treatment) because from our past experience of working with J.S., a longer hold seemed necessary to best treat her psychosis. 
While we waited for the Probable Cause Hearing, the patient's attorney asked if she could meet with the treating physicians. During our meeting she stated that she favored treatment for J.S. She then went over the T.D.A. document almost word for word. The attorney wanted to know if this could be worked out without commitment. We strongly felt that it couldn't. She then stated that she didn't think commitment was necessary, and that she had ways to get patients released. She related to us cases where she "successfully" had clients' cases dismissed on technicalities. The attorney also referred to cases in which doctors had coerced their patients to file R.F.D.'s and made it clear that this better not be the case with Miss S. With this we abruptly ended out meeting.

After that, I had to call the Milwaukee County attorney to discuss the case and convince myself that we had a good case. I read my T.D.A. to him over the phone, and he stated that he thought we had a good case and that we should proceed. I felt a little better, but still slept poorly.

The day of the hearing I dressed for success. Just prior to the hearing, I again talked with the county attorney. He read over the T.D.A. and stated that it was written well and that we shouldn't have any problem. We entered the courtroom and sat down. Miss. S. was on the other side of the courtroom with her attorney. Then something happened that I couldn't have imagined. Her attorney made a motion to have all unnecessary spectators removed. She pointed out that since my supervisor wasn't listed as a witness on the T.D.A., she had to leave! It was granted. I felt responsible and was beginning to worry. Then she made another motion. This time it was for dismissal on a technicality! The attorney stated that because of insufficient dates and abbreviations on the document, as well as because witnesses were not present, the case should be dismissed. The county attorney argued that because I was a physician listed on the document, and could testify as to the nature of the medical evidence, the case should proceed.

The court commissioner looked over the T.D.A. and stated that because I hadn't placed a date on the progress note attached to the formal document (this was an addendum to add information as the space on the T.D.A. is limited) and because of abbreviations (F.M.L.H. was given as an example) that were used which were not understandable to her, the case was dismissed "without prejudice." I had no idea what "without prejudice" meant. My jaw dropped. I didn't even have a chance to testify. There was a date on the front of the T.D.A. document, and everyone I worked with knew the abbreviation for Froedert Memorial Lutheran Hospital. Besides, all these things had been discussed with the patient's attorney on the previous day. I could barely swallow. Later I realized that I was feeling angry, and that much of the anger was directed toward myself. No one would hear how close to death the patient had come, and it didn't seem to matter.

The patient refused any voluntary treatment and was discharged by court order. The ironic thing was that Miss. S. even chose to fire her attorney after the hearing. I wondered if I would ever see J.S. again.

Later that afternoon, I telephoned one of the county's attorneys and discussed my concerns for the patient's health (and life). He recommended another alterna- 
tive. He explained that "dismissal without prejudice" meant the commitment case could be retried based on the same evidence. I made an appointment at the Milwaukee County Courthouse to pursue a P.E. The three parties would be the patient's father, my attending psychiatrist and myself.

It was during one of these contacts with J.S.'s father that I lost even more faith in the legal system. He told me that after the case was dismissed, the county attorney told him that if the doctor had done a better job writing the T.D.A., he wouldn't have lost the case. I realized the attorney was talking about me! Maybe he needed to protect himself more than he needed to protect me. This was the same attorney who had looked over the T.D.A. and said it was adequately written.

We met at the courthouse the following Monday. This time we were extremely careful with the preparation of the documents. A different county attorney went over the documents word by word.

Later that week, Miss S. was picked up by the police on the basis of the P.E. She was admitted to the same inpatient unit. Probable cause for commitment was found, and two weeks later Miss S. was committed to treatment. This time around, I even testified. Because of the patient's poor compliance with medication, we also filed for a medication hearing (to require J.S. to comply with neuroleptic treatment). In Wisconsin, civil commitment does not require patients to comply with medication treatment. Instead, an "Order to Treat" which is a declaration of the patient's incompetence to make a treatment decision, must be obtained in order for the hospital to treat with medications, and that too was granted.

From the time Miss S. was in kidney failure until the time she was committed to treatment and medication was nearly eight weeks. The time frame exceeds four months if you go back to the time she walked out of the unlocked unit A.M.A. That's a lot of time, effort, suffering and money spent.

Now, eighteen months later, J.S.'s commitment continues. She agreed to extend it two more times. I still work with her in my outpatient clinic. (No, I didn't quit my residency or move out of the state!) It was an uphill battle to improve my rapport with her, but it was well worth it. She now gets Prolixin decanoate every two weeks, and has been without psychotic symptoms for over a year. Recently, she even began working a part-time job, and her self-esteem continues to improve.

This case report may show the importance of a commitment system, but I intended to illustrate the workings of the Wisconsin civil commitment process as it operates in Milwaukee County, to point out some of its many problems, and to give some suggestions as to how these problems can be dealt with.

The process seems to create a triangulation between the medical system, the legal system, and the patient. Because of this, problems may occur at any of the three interfaces. Being a part of the medical system allows me to see two interfaces especially well. The medical-legal interface seemed to present the most problems, and they centered around either of the systems trying to or being required to do what would seem to be the other system's job. Examples of this are the physician's being expected to file a legal document without the help of an attorney, and the police 
officers' deciding about dangerousness without a thorough understanding of what can be medically dangerous.

Some of the solutions to these problems are obvious: require the physician to have an attorney present upon filing a legal document. Others are not so easily solved. Can we train our judges or police officers to understand medical $/$ mental illness? Probably not to the extent that would be necessary. Should we have physicians filing E.D.'s? It seems to me that the answer lies more in the communication between the systems. Instead of trying te train physicians to be police officers or attorneys and vice-versa, we need to better coordinate our efforts.

The other interface that I could view exceptionally well from my vantage point is that of the medical system-patient. The major problem here is that the psychiatrist and the patient are pitted against each other, turning the relationship into an adversarial one. The rapport which the physician has worked so hard to develop can be thrown right out the window. What seemed to salvage some of the rapport for me in the case of J.S. was my telling her that what was happening was for her own safety, and that my hands were tied by her condition and the law. I was doing what I had to do. I think what makes this a good approach to this problem is that it's honest, and it puts the responsibility on the patient for getting into the situation that brought them into the commitment process.

\section{REFERENCE}

1. Wis. Stat. Sec. 51.001-51.95 (1990).

\section{GLOSSARY}

1. Emergency Detention (E.D.): An E.D. is a police hold which allows the individual to be held against his or her will for up to 24 hours because of behavior which a police officer feels is dangerous to the individual or others. The police officer must also feel or have evidence that the individual's dangerousness is in some way related to mental illness (and/or drug dependent or developmentally disabled.)

2. Probable Cause Hearing: A Probable Cause Hearing is a preliminary hearing at which a judge (or court commissioner) decides if there is a probable cause for commitment. Probable cause is found if there is evidence of mental illness (and/or drug dependent or developmentally disabled) and dangerous.

3. Request for Discharge (R.F.D.): An R.F.D. is a document the voluntary patient can request to sign which puts in writing his or her wish to be discharged. From the time this wish is made known to the treating staff, the treating physician has up to 24 hours to address this. When addressing this, the physician can either release the patient or file a "Treatment Director's Affidavit."

4. Thirty Day Voluntary Case Suspension Agreement (30 day V.C.S.A.): The 30 day V.C.S.A. is a legal agreement between the patient and the treating physician which places the commitment procedure on hold for up to 30 days. If at any time during that 30 day period, the treating physician feels that commitment must be pursued (this is often done when a patient is poorly compliant with treatment), he or she may reject the 30 day V.C.S.A. and this pushes the case back into the commitment procedure. 
5. Three Party Petition (P.E.): A P.E. is one of the procedures which can be pursued in order to have an individual committed. It requires the signatures of three separate parties as well as written testimony that the individual in question is mentally ill (and/or drug dependent or developmentally disabled) and dangerous.

6. Treatment Director's Affidavit (T.D.A.): A T.D.A. is a legal document which the treating physician must complete to assert that a voluntary patient who has filed an R.F.D. is dangerous and is mentally ill, drug dependent, or developmentally disabled, and thus a candidate for commitment. This then places a legal hold on the patient and a Probable Cause Hearing must then be held within 72 working hours.

7. Treatment Director's Supplement (T.D.S.): A T.D.S. is a supplemental legal document filed by the treating physician which allows the legal hold to be extended for another 48 hours beyond the 24 hours of the E.D., at the end of which a Probable Cause Hearing will be held. 